\title{
Burāq depicted as Amanita muscaria in a 15th century Timurid-illuminated manuscript?
}

\author{
ALAN PIPER* \\ Independent Scholar, Newham, London, UK
}

(Received: May 8, 2019; accepted: August 2, 2019)

\begin{abstract}
A series of illustrations in a 15th century Timurid manuscript record the mi'raj, the ascent through the seven heavens by Mohammed, the Prophet of Islam. Several of the illustrations depict Burāq, the fabulous creature by means of which Mohammed achieves his ascent, with distinctive features of the Amanita muscaria mushroom. A. muscaria or "fly agaric" is a psychoactive mushroom used by Siberian shamans to enter the spirit world for the purposes of conversing with spirits or diagnosing and curing disease. Using an interdisciplinary approach, the author explores the routes by which Burāq could have come to be depicted in this manuscript with the characteristics of a psychoactive fungus, when any suggestion that the Prophet might have had recourse to a drug to accomplish his spirit journey would be anathema to orthodox Islam. There is no suggestion that Mohammad's night journey (isra) or ascent (mi'raj) was accomplished under the influence of a psychoactive mushroom or plant.
\end{abstract}

Keywords: Mi'raj, Timurid, Central Asia, shamanism, Siberia, Amanita muscaria

\section{CULTURAL CONTEXT}

\section{The mi'raj manuscript}

An illustrated manuscript depicting, in a series of miniatures, the successive stages of the mi'raj, the miraculous ascent of the Prophet Mohammed through the seven heavens to receive God's instructions for the faithful was produced in 15th century in the city of Herat (Séguy, 1977). This text of the mi'raj story is in Turkish, in the Uighur script. The manuscript was purchased, on behalf of the French Ambassador, in 18th century Constantinople, and it currently resides in the Bibliothèque Nationale in Paris, France as Manuscrit Supplément Turc 190.

Herat, today in Western Afghanistan, has been a crossroads of trade and culture for hundreds of years and formed an important stop on the Silk Route. When the Arabs captured Herat in $660 \mathrm{CE}$, it became a center of the Muslim world. The Mongols swept through and took control of Islamic Central Asia in the 13th century, and Herat went into decline after being sacked by Genghis Khan in 1222-1223. However, control of most of Asia by the Mongols soon created an environment of tremendous cultural exchange and Eastern and Central Asian influences became evident in Islamic art. Timur-i Lenk, the Turkic conqueror, better known in the West as Tamerlane, took Herat in about 1393, initiating its greatest era under Timurid rule, when it became a center of science and culture. The mi'raj manuscript illustrations are a product of the Herat school, a style of miniature painting that flourished in the 15 th century under the patronage of the Timurids.

\section{Burāq depicted as Amanita muscaria in the mi'raj manscript}

In the Muslim tradition, the mi'raj was preceded by the isra or "Night Journey" during which Mohammed traveled overnight from Mecca to Jerusalem by means of a fabulous beast called Burāq. In some versions, the Prophet's ascent is also accomplished by the agency of Burāq. According to tradition, at the site of the Temple Mount in Jerusalem, known to Muslims as Haram esh-Sharif ("the Noble Sanctuary"), Mohammed ascended through the seven heavens in the company of the angel Gabriel, to receive God's instructions for the faithful. Burāq is described as being a creature larger than a donkey but smaller than a mule and is usually depicted as an equine creature with a woman's head and sometimes, but not always, with wings (Hajjāj, 1989; Vuckovic, 2005).

Seale in her visual history of Burāq (2016) notes that Burāq is "a creature not of scripture but of lore," first appearing in an 8th century biography of Mohammed. The iconography of Burāq from Persian miniatures to the decoration of Pakistani trucks is such that "there is no original, no definitive Buraq, but rather an unruly palimpsest of jumbled creeds, kitsch, and sheer artistic caprice." Depictions of Burāq vary from frankly equine to various chimeras mixing human and various animal parts (Seale, 2016). The plethora of literature concerning Muhammad's ascension to heaven "slipped its scriptural moorings and

* Corresponding address: Alan Piper; Independent Scholar, 56 Meath Road, Newham, London E15 3DR, UK; Phone: +44 7882 816332; E-mail: tzanjo@googlemail.com

This is an open-access article distributed under the terms of the Creative Commons Attribution-NonCommercial 4.0 International License, which permits unrestricted use, distribution, and reproduction in any medium for non-commercial purposes, provided the original author and source are credited, a link to the CC License is provided, and changes - if any - are indicated. 
slid out into poetry and folklore" and Burāq's body became "a receptacle for the many myths, metaphors, and moral concerns that Islam inherited."

Several of the illustrations in the Herat manuscript depict $B u r a \bar{q}$ with the distinctive red and white spotted skin of the A. muscaria mushroom, exact in the smallest detail. That is to say, they both share a distinctive shade of red as a background color, which is covered by small circular or oval white patches that have ragged edges and, when aged, a darkened center (Figure 1). The pattern and color for the Prophet's piebald mount could be the result of an imaginative flight of fancy of the artist, unrelated to the appearance of any mushroom. While the suggestion that the Prophet might have had used a psychoactive drug to accomplish his spirit journey would be anathema to orthodox Islam, there is a variety of evidence that supports the possibility that this illustration could represent the translation into art of Central Asian shamanic traditions, in which the Prophet's miraculous heavenly ascent was interpreted by the artist in terms of a spirit journey accomplished by the agency of the fly agaric mushroom. The author will draw on botanical, linguistic, and ethnographic evidence, as well as the history of religious ideas and folklore, to support the conclusion that the depiction of Burāq with the distinctive features of A. muscaria is not the product of chance.

I must make it clear that I am not in any way suggesting that Mohammad's night journey (isra) or ascent ( $m i$ 'raj) was accomplished under the influence of a psychoactive mushroom or plant. I am only asserting that, as Islam extended its influence, the isra and mi'raj narratives were adapted to different cultural milieus. In the case of the Timurid miniatures, an artist may have embellished Burāq with a hide resembling the skin of a psychoactive mushroom based on local awareness of shamanic journeys accomplished in this way. Although accounts of the isra and mi'raj are based on a very brief scriptural reference in the Quran, as agents of missionary conversion and as important assertions of Mohammad's divine authority, these narratives "have been developed and transformed in fascinating ways in the diverse contexts in which the story was told and retold over may centuries" (Gruber \& Colby, 2010).

Nor am I suggesting that Mohammed would necessarily be seen as a shaman rather than a spiritual leader, except in the sense that his spirit journey could be seen as comparable to those accomplished by a shaman, by those for whom the narrative fitted this context. In Central Asia, shamanism was combined with elements of Sufism to adapt to wider Islamic society. To this day, "islamised shamanism" for the purposes of healing and divination, accomplished through personal relations with spirits, continues to exist in Kazakhstan, Uzbekistan, Tajikistan, Kirghizstan, Northern Afghanistan, the Turkoman province of Iran, and the Uygur district of Xinjian province of China (Zarcone \& Hobart, 2016).

\section{The mi'raj as an otherworldly journey in the shamanic tradition}

The word mi'raj means "ladder" in Arabic, which is a ladder in the tradition of Jacob's ladder in the Old Testament story, reaching from earth to heaven with the Angels of God ascending and descending upon it (Vuckovic, 2005). Mohammed's ladder may be compared to the notched tent pole by means of which Siberian shamans are sometimes described as accomplishing their celestial ascents (Stone, 1992). Since the mi'raj tradition first attracted critical scholarly attention, a variety of authors have identified the mi'raj as drawing on earlier Judaeo-Christian accounts of heavenly ascent such as the Book of Enoch and Iranian traditions such as the Arda Wiraf narrative (Vuckovic, 2005). In the Arda Wiraf narrative, a righteous man is chosen to visit the spirit world by means of a narcotic potion of wine and Cannabis or Henbane (Flattery \& Schwartz, 1992) to determine if the existing forms of Zoroastrian of worship were pleasing to God (Haug \& West, 1971).

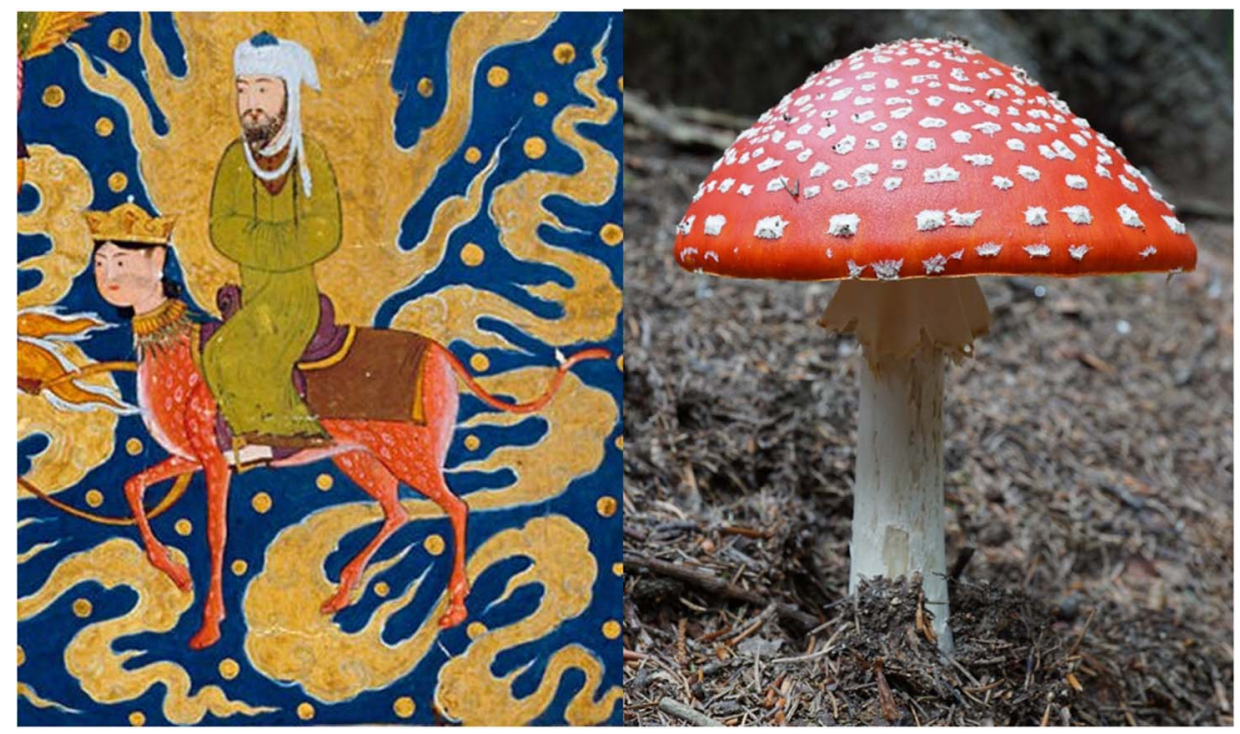

Figure 1. Detail from page showing the Night Journey (Mi'raj) of the Prophet Muhammad from, Mira'j-nameh, Manuscrit Supplément Turc 190. Adjacent is a typical example of Amanita muscaria mushroom. Image source of mirajnameh: https://commons.wikimedia.org/wiki/File: Miraj-BNF-1436.jpg. Image source of A. muscaria: https://commons.wikimedia.org/wiki/File:2006-10-25_Amanita_muscaria_crop.jpg. A full sequence of images from the mirajnameh can be freely viewed at: https://gallica.bnf.fr/ark:/12148/btv1b8427195m/f39.image 
The dependence of the mi'raj story on earlier Iranian and Judaeo-Christian narrative traditions, or their common sources, is still maintained along with the assumption that these traditions reflect earlier shamanic traditions widely diffused throughout Eurasia (Culianu, 2001; Séguy, 1977; Vuckovic, 2005). The traditional descriptions of Mohammed's experiences on his journey include a number of elements that are stereotypical of intoxication by hallucinogenic plants. These elements include distortions of the perceived size of objects; iridescent halos around people and objects; multiple images as under stroboscopic light; everything appearing bejewelled; objects veiled in moving patterns; visions of fantastic animals and vegetation; and a generalized intensification of the all the senses (Hajjāj, 1989; Séguy, 1977). Key elements of the mi'raj story are present in shamanic spirit journeys, including those that have been recorded as typical of the use of $A$. muscaria (Schurr, 1995).

These include:

- helping spirits guide the shaman through the spiritual topology of the supernatural world;

- exploration of the sacred cosmology;

- information from the supernatural realm is to be reintegrated into the daily lives of group members;

- on return from the supernatural realm, the shaman relates his visions to those around them and reports discussions with dead kinsmen.

The angel jibril (Gabriel) accompanies and guides Mohammed on his journey. Mohammed is taken in turn through the seven heavens and there meets and converses with his ancestors; former prophets such as Adam, Noah, Idris (Enoch), Abraham, Moses, and Jesus. Mohammed returns with the instructions for worship by the faithful and relates the pleasures of the pure in paradise and the punishments meted out to sinners in hell (Culianu, 2001; Vuckovic, 2005).

\section{THE EXTENT AND DIFFUSION OF $A$. MUSCARIA AND ITS USE AS AN INEBRIANT}

\section{Global distribution and usage}

Amanita species are widely distributed throughout the planet. A. muscaria grows in summer and fall under coniferous and deciduous trees, from the lowland up to the sub-alpine zone. It occurs practically all over the temperate and subtropical zones in Europe, North Africa, South Africa, Asia, Japan, Australia, North America, and in South America (Seeger \& Stijve, 1978). Like a number of other mushrooms, the mycelium of the A. muscaria cannot establish itself other than in symbiosis with the root system of certain species of trees. In the case of $A$. muscaria, it is particularly associated with the birch and pine, sacred trees throughout Eurasia.

Prior to invading and establishing a Central Asian empire, the original homeland of the Mongols lay on the fringes of Siberia around the Altai Mountains of Siberia, an area rich in pine and birch trees (de Hartog, 2004), the essential symbiotic hosts of $A$. muscaria. The Turkicspeaking Mongols' favored intoxicant is alcohol in the form of the fermented mare's milk or "koumis." The arrival and availability of alcohol has been viewed as displacing the indigenous use of Amanita in the 20th century (Salzman, Salzman, Salzman, \& Lincoff, 1996) and Amanita usage may have been more extensive in the past. Conversely, $A$. muscaria has been used by soldiers as an inebriant in the absence the availability of alcohol (Wasson, 1972).

Prolific reports of the use of $A$. muscaria as an inebriant were recorded among the indigenous peoples of Siberia, by Russian and European traders, missionaries, and explorers from the 17th century onwards (Wasson, 1972). The majority of records of contemporary use of $A$. muscaria as an inebriant by indigenous peoples is confined to reindeerherding peoples who speak languages in the Uralic family. These include the Samoyedic or Finno-Ugric groups in Western and Northern Siberia and peoples in the extreme east of Siberia who speak isolates, Paleosiberian languages without any known linguistic relationships to other language families, such the Chukchi (Salzman et al., 1996). Riding a horse or reindeer through the sky is a common metaphor for shamanic spirit journeys in Siberian shamanism and sticks with the head of a reindeer or horse and sometimes both are a tool and badge of office for apprentice shamans in Siberia (Stone, 2003). Reliable reports record that "Ostyak and Vogul tribes in western Siberia and Kamchadal, Koryak, Chukchi tribes in eastern Siberia, still use A. muscaria for shamanistic rites" (Michelot \& Melendez-Howell, 2003, pp. 131-146). However, the contemporary use of $A$. muscaria has also been recorded in Tibet (Müller-Ebeling et al., 2000), Afghanistan (Mochtar \& Geerken, 1979), Spain (Fericgla, 1992), South Africa (Miller, 2001), and North America, where Peschel (1998) writes of the traditional use of $A$. muscaria by the Ahnishinaubeg (Ojibway) people who live near Lake Superior. Among the indigenous peoples of Siberia, A. muscaria also has medicinal uses as a tonic or to help the elderly sleep (Lincoff, 2005; Saar, 1991). There is artifactual evidence suggesting that historical use in a shamanic context in South America (Furst, 1986) and an awareness of its intoxicating effect in association with altered states of consciousness is indicated in folklore throughout Europe (Fericgla, 2001).

\section{Distribution of mushroom words in Eurasia}

In a number of Ugrian languages, mushrooms, and in some cases, the A. muscaria specifically, are referred to as pânkh in Mansi (obsl. Vogul) pango, panga (Mordvinian), pongo (Cheremis), and in northern Mansi pânkh also means "intoxication, drunkenness" (Eliade, 2004). All of these words have the same roots as words in Indo-European (IE) languages such as the Spanish hongo, mushroom, English "fungus" and "sponge," from Latin spongia, Greek spongos. The same IE root is evident in words for mushroom in languages of the Indian subcontinent $k h u m b(\bar{l})$ and phung $\bar{l}$ (Sindhi), (k)humb $(\bar{l})$, (Hindi) and in Afghanistan Pashto: Waziri xōmba (Morgenstierne, 1957). This root is also evident in the modern English term "(s)punk" for tinder derived from dried tree fungus, Polyporus fomentarius. Wasson (1972) cites several references in the Vedic scriptures to soma, the sacred drug of Hindu scriptures dating to the third millennium BCE, which he believed to be A. muscaria, as the "mainstay of the sky." 
In Graves' study of proto-religions in Central Asia, he supplies a panga/pongo/hongo type word list, which he links not to fungus/mushroom, etc., but to a Chinese deity called P'an $K u$ who is "a pillar of the sky." P'an Ku swells from an egg-shape until he supports the sky above the earth like a mushroom (Graves, 1994). Stone (1992) discusses A. muscaria as Axis Mundi, the white speckles on the mushroom cap-like stars on the dome of the heavens. The wide historical and geographical dissemination of (s)pongtype mushroom words, in both Uralic and IE languages, from Western Europe to Siberia and the Indian subcontinent, suggests an extremely ancient Pan-Eurasian cultural distribution of the use and knowledge of fungi, possibly with shamanic roots.

Although in Finno-Ugric languages, pango-type words are specifically associated both with $A$. muscaria and words relating to intoxication in general (Balázs, 1996), it is possible that the original reference is to the shape of the growing mushroom's cap, in words meaning "hump," "bump," "ball," and "sphere" as in Sanskrit in which kumbha means "hump" (Morgenstierne, 1957). In Hungarian, gomba is "mushroom;" gomb is "button" or "knob;" and gömb is "ball," "orb," "bellshaped," and "globular" (Országh, 1987). In Hungarian, 16 names refer expressedly to A. muscaria, including several which refer to its power to intoxicate, such as bolondgomba, "crazy mushroom," táncgomba, "dance mushroom," bukfencgomba, "somersault, crazy mushroom," and also mesegomba "mushroom of fairy tales" (Zsigmond, 2003). Hungarian contains many words of clearly Turkic origin and claims for Hungarian as both a Finno-Ugric and Turkic language have both been made. Certainly, there was close contact between Turkic and Finno-Ugric speakers at some point in the emergence of the modern Magyar (Hungarian) peoples.

\section{Indications of the antiquity of A. muscaria usage}

Bronze Age petroglyphs, discovered on the Pegtymel River in North-Eastern Siberia, depict human figures with mushroom caps for heads or above their heads (Devlet, 2008; Golovnev, 2001). The petroglyphs have been quite logically associated with use of A. muscaria, which continues there among the indigenous Chuckchi peoples, in an unbroken tradition to this day (Devlet, 2008) and are featured in the film Pegtymel (2001) by Dr. Andrei Golovnev, Arctic anthropologist and filmmaker and a leading expert on indigenous peoples and cultures of the Russian North. The illustrations of petrogylphs from the Pegtymel region used are taken directly from the ethnographic film Pegtymel (2001), made by Professor Andrei Golovnev, member of the Russian Academy of Sciences, and have been converted to black and white for clarity. An additional source for examples of mushroom iconography in the Pegtymel petroglyphs can be found in Devlet (2008). A discussion of questions of interpretation and illustrations of the Pegtymel' (sic) petroglyphs can be found in PART III, PEGTYMEL' PETROGLYPHS, in Kiriak (2007). A short discussion of the petroglyphs and illustrations can also be found in the study of Gosso and Webster (2014). These petroglyphs depict what may be either anthropomorphic mushroom spirits, as experienced in a state of mushroom intoxication, or individuals themselves under the influence of hallucinogenic mushrooms, so indicated by placing a mushroom motif in place of or above their heads (Figures 2-5).

\section{Pegtymel Petroglyphs (Golovnev, 2001)}

Barkalaja (1997) has conducted field research among the Khanty (obsl. Ostyak) peoples, who inhabit a vast area of swampland in North-Western Siberia. According to Barkalaja (1997), for the Khanty, pong (A. muscaria) is the intermediary between the shaman and God. Pong communicates by turn questions and the answers journeying to the

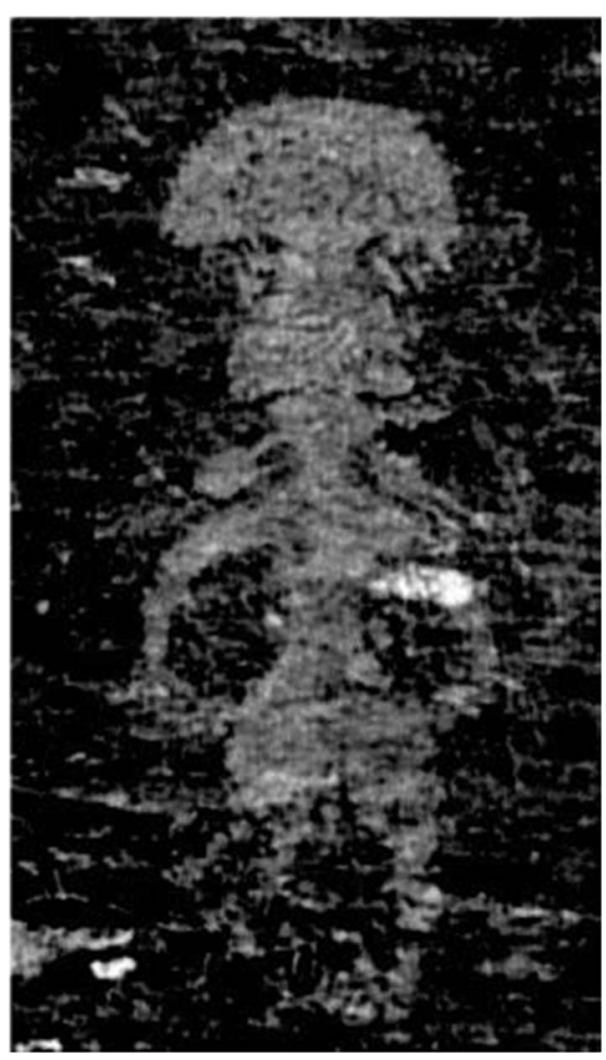

Figure 2. Mushroom Maiden

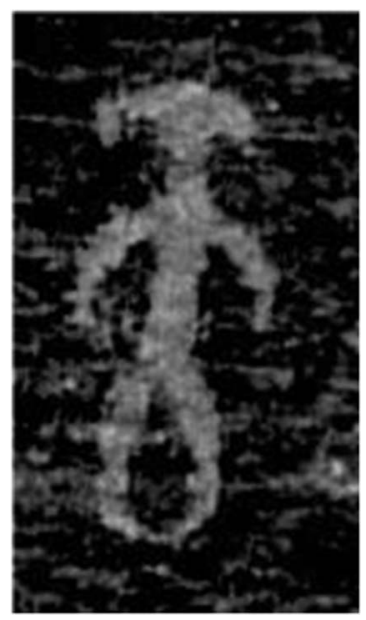

Figure 3. Male companion 


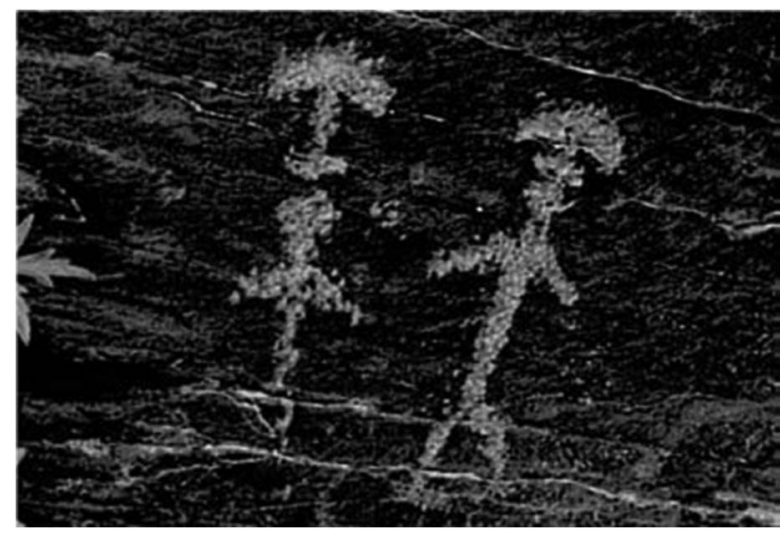

Figure 4. Mushroom men

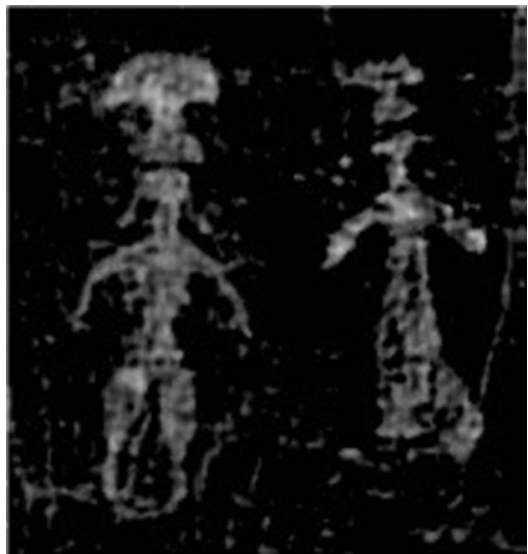

Figure 5. Mushroom women

heavens and back. In some regions, the spirit of the Khanty shaman himself travels after eating pong. In others, it is not the shaman who sings at a ritual, but the mushroom spirit; the shaman merely repeats the songs sung to him by the spirits of the mushroom. This notion is congruent with that of the Mazatecs, indigenous peoples of Oaxaca, Mexico, who use psychoactive mushrooms of the genus Psilocybe. In trance, it is the mushrooms who speak. "If you ask a shaman where his imagery comes from, he is likely to reply: I didn't say it, the mushrooms did" (Munn, 1973, pp. 86-122). Among the modern Chuckchi of the Pegtymel region, an elder, describing his visions under the influence of $A$. muscaria, corrects his wife's remark, "remember you were telling me once that you took vapak (A. muscaria) and saw dead people," by saying "I didn't see them the vapak saw them" (Golovnev, 2001). According to the Chukchi, "when you take vapak you feel as if you are walking, your legs are yours, but the head is another's, the head of the mushroom. You are not a human anymore but a spotty mushroom, vapak" (Golovnev, 2001). Devlet (2008) reports mushroom-like rock art images from Chukotka, South Siberia, and Central Asia and associates them with ethnological observations of the extant practice of eating $A$. muscaria among the Chukchas. Cheremisin (1997) reports depictions of human figures in mushroom-shaped "headdresses" as widespread in the rock art in Central Asia and in Southern Siberia, in Tuva, the Mongolian Altai, in Northern
China, and Inner Mongolia, but challenges their connection with an A. muscaria cult. However, the Pegtymel petroglyphs are so evocative of the traditional conceptions of mushroom intoxication by Siberian and other indigenous peoples that any alternative interpretation would need strong evidential support, given the documentation of existing traditions of eating A. muscaria in the same location.

\section{Folk use of $\boldsymbol{A}$. muscaria as an inebriant in modern Afghanistan}

Contemporary use of $A$. muscaria as an inebriant in Central Asia was discovered in Afghanistan during the 1960s, by Said Ghoulam Mochtar and Hartmut Geerken. They made several mycological expeditions to the Shutul Valley, a side valley of the River Panjshir, which rises in the Mountains of the Hindu Kush to the north of Kabul, in eastern Afghanistan. There they were able to question several older male inhabitants of this secluded mountain valley about the use of $A$. muscaria, which both plays a recreational role and has applications in folk medicine there (Mochtar \& Geerken, 1979). Inquiring about its occurrence and use, Mochtar and Geerken were informed that A. muscaria, locally called Nan-e-saghta, "Raven's Bread" is gathered in the late spring of wet years and dried in the hot sun. In this way, the mushroom is almost permanently preserved. The association of ravens with $A$. muscaria also occurs in Siberian folk tales. A Koryak tale relates how the powers of the mushroom we revealed to the culture hero, Big Raven, by God to achieve a Herculean task. Big Raven says afterward: "Let the Agaric remain on earth and let my children see what it will show them" (Waldemar, Kasten, \& Dürr, 2016, p. 162).

In the Shutul Valley, dried A. muscaria is ground to a powder by the inhabitants for its use as an inebriant. They boil the Amanita powder with fresh mountain snapweed and soured goat-cheese brine, and in this way produce a wellknown local specialty, "Extract of Shutul." In the hamlet of Qaf-e-Changar, at the upper reaches of the Shutul, the calyxtips of seed-bearing flowers of the black henbane, Hyoscyamus niger, are added to the extract. It is used for purposes of therapeutic massage, coming into effect by means of transcutaneous stimulation. An external application of $A$. muscaria is also used by the Khanty of Siberia for treatment of snakebite (Saar, 1991).

During their excursions, Mochtar and Geerken (1979) were able to tape-record the reports of elderly inhabitants of the valley, describing their experiences under the influence of the mushroom.

- Farid Ahmad (aged around 60 years): "[around 15 minutes] after I drink the extract, a feeling of weariness and a need for sleep overcomes me. I hear voices, although I am alone in my room.... I laugh about the voices and about myself..."

- Mustafa (aged around 60 years): "First, I am very sleepy, then I feel good. I forget sentences .... Once I thought that I was a tree..."

- Ahmad Kargar (aged about 65 years): "I have drunk it for many years, yet only once have I had a really bad time. I was anxious and afraid; I ran around in the woods and didn't know who or where I was..." 
- Malang Aziz (aged between 60 and 70 years): "We don't have much, but we have Raven's Bread. We grind it down to a gray powder and make a concoction of it .... In Winter, when we can't leave the house, we drink it."

In the Shutul Valley, the preparation and use of $A$. muscaria would appear to exist only as an archaic practice among the valley's older inhabitants. Mochtar and Geerken (1979) conclude that it should be of great interest to mycologists that these vestiges of a mushroom cult have survived until our day in one remote mountain valley in the Hindu Kush, "and perhaps others elsewhere?"

\section{BURĀQ, SHAMANISM, AND THE THEME OF REGURGITATION}

\section{Burāq and baraq as Mount of the Shaman}

Dankoff (1971) explores the relations in language and myth between the Turkic baraq referring to the "mount of the shaman" and the Arabic Buraq, the fabulous mount by means of which Mohammed accomplishes the isra and sometimes the mi'raj. He identifies the routes by which the Middle Iranian bārak, thorough linguistic borrowing, came to designate, on the one hand, the Arabic Burāq Mohammed's spirit mount and on the other the Turkic baraq to designate the "mount of the shaman," a "shamanic animal," or "the shaman himself." In the early 13th century, in Turkey, Syria, and Iran, dervishes of wild appearance gathered around a nominally Muslim spiritual leader called Barak Baba (Karamustafa, 1994). Of special interest is the manner in which Barak Baba received his name. In a version of the story cited by Dankoff, while Saru Saltuk (Barak Baba's spiritual master) was yet a shepherd, Seyyídi Mahmud (Baraq Baba) paid him a visit and placed in his mouth a morsel of food along with some yogurt. This morsel was like a piece of matted cloth, the size of a bean, and stuck to his upper palate. Saru Saltuk at once had a fit of vomiting, and this morsel fell out with his vomit. The prince had fallen into a trance at Saru Saltuk's discourse, and he now ate up the vomit. Saru Saltuk caressed him and called him "my baraq" (Dankoff, 1971, pp. 109-110).

\section{Regurgitation in association with mushrooms and shamanism}

While eating someone's vomit might appear disgusting to modern western tastes, it was not foreign to Siberian cultures as the following 19th century account makes clear. "If the Yakut was a good and loving spouse, he would go directly home and eject the contents of his stomach into a vessel of water, which then he placed out of doors to cool and collect; and from the rich, floating vomit his wife and children would afterward enjoy a hearty meal" (Melville, 1885 , p. 318). This practice also formed part of the ritual employment of $A$. muscaria as an intoxicant in Siberia. A shipwrecked seaman, who had been rescued by the Siberian Chukchi, with whom he remained some 2 years, described their way of making an intoxicating liquor in this way,
... in the summer, mushrooms or fungi were collected in large quantity, and eaten by a man who, like our Indians, prepared himself by fasting for the feast. After eating enormous quantities of the fungi, he vomited into a receptacle, and again loaded up, time and again, and disgorged the stuff in a semi-fermented or half-digested condition. It was swallowed by those who were waiting for the drink; and his urine was also imbibed, to aid in producing a debauch, resulting in frenzied intoxication. (Bourke, 1891, p. 74)

The theme of regurgitation in association with a spirit helper in the guise of a mushroom turns up in Finnish folklore. According to the Victorian folklorist Keightley (2000), a type of Finnish goblin steals the milk from other people's cows, carries, and coagulates it in his stomach and then disgorges into his mistress's churn. In this connection, Keightley states that there is a species of mushroom which, if it is fired with tar, salt, and sulfur and then beaten with a rod, will cause the woman who owns the goblin to quickly appear and beg to spare him. That is to say, the mushroom's role as an assistant or familiar spirit, by means of which his mistress accomplishes her sorcery, is thus revealed. Siberian shamans view $A$. muscaria consumption as a means of creating assistants to assist them in contacting the supernatural world (Schurr, 1995).

In this connection, it is relevant that, in Norse mythology, Odin by means of transforming first into a snake and then into a bird, steals, swallows, and then regurgitates the "mead of inspiration." He thereby makes it available to man, endowing those privileged to drink it with the gifts of poetic composition. A lesser portion is excreted from his other end for the benefit of a lower class of poet. Among populations using $A$. muscaria for shamanic purposes, transformation into animals is a typical experience of $A$. muscaria intoxication (Schurr, 1995) and in this guise the shaman is able to perform supernatural feats. The recurrent theme in folklore of a magical food that endows men with supernatural talents is certainly a reference to the consumption of psychoactive substances and the talents supported by A. muscaria in Siberia include assistance in the recital of epics (Schurr, 1995).

\section{EVIDENCE OF A. MUSCARIA USAGE IN THE TIMURID RELIGIOUS MILIEU}

\section{A. muscaria in Tantric Buddhism}

The imbibing of bodily fluids and other excrementa is a feature of the esoteric schools of Buddhist and Hindu Tantra, in connection with initiation and transcendental mind states (Crowley, 1996; White, 2003). It is possible that the depiction of $A$. muscaria in the Timurid manuscript as the agency of the Prophet's ascent reflects an awareness of its properties assimilated from Tibetan Buddhism. There is intriguing evidence for the use of $A$. muscaria not only as recorded in contemporary Tibetan shamanism (MüllerEbeling et al., 2000), but also in the Tantric traditions of Tibetan Buddhism found in Tantra's classical texts (Crowley, 1996; Hajicek-Dobberstein, 1995). Although later largely supplanted by Islam, many Mongols had 
adopted Buddhism early in the 13th century as they were exposed to the religion in China, Tibet, and Northern India (Nicolle, 1998, pp. 134-140). Ghengis Khan's grandson, Hülegü (1217-1265), the first Khan of the Ilkhanate of Persia, adopted some Buddhist customs. He considered himself a devotee of the Boddhisattva Maitreya (Nicolle, 1998, pp. 134-135), but is primarily regarded as a traditional Mongol shamanist (Heissig, 1980).

\section{Influence of Buddhist and Hindu esotericism on Islamic mysticism}

Buddhism was "the most important civilized religion among the first Il-Khans. Buddhist monks came from China, Tibet and Uighur Central Asia" (Nicolle, 1998). Hülegü's brother, Kublai Khan (1215-1294), adopted the slightly unorthodox Tibetan lamaist version of Buddhism and made Buddhism the state religion when he became Khan of the Mongols in 1260. Hülegü's grandson, Arghun (1258-1291), "brought both Buddhist priests and men skilled in yogic mysticism from India. It is even possible that Buddhist yogis and the half-shamanist bakshi ascetics in the Il-Khan Court influenced the development of certain later forms of Islamic Sufi mysticism. This in turn influenced aspects of modern Iranian Sh'ia Islam" (Nicolle, 1998, p. 135).

According to Heissig (1980, p. 4):

...through close contact with the Turkic Uighurs settled in the cities, who practised Buddhism, Manichaeism and Nestorianism, ideas from these religions penetrated among the Mongols, above all the Manichaean concepts of light, the figure of Hormusta, the Ahuramazda of the Persians.

Besides being written in Turkic in the Uighur script, the Timurid illustrated manuscript of the mi'raj reveals Buddhist and Zoroastrian (Iranian) influences in its iconography (Séguy, 1977). In Zoroastrian tradition, the conversion of legendary King Vishtasp recorded in the Zoroastrian scriptures to Zoroaster's religious message is achieved when Ahuramazda instructs an angel to carry up to Vishtasp a potion described as "that fountain of life, for looking into the existence of the spirits, the enlightening food by means of which great glory and beauty are seen by Vishtasp" (West, 1987). The possible use of A. muscaria by the Manicheans, who are condemned in a medieval Chinese text for eating red mushrooms, is cited by Wasson (1972).

Influences from Islam were joined by those from the earlier assimilation of Buddhism and the indigenous shamanistic conceptions of the Mongols. This resulted early in a predominance of syncretistic thought and the fusion of motifs from different religious traditions (Nicolle, 1998, pp. 134-140). The practices of Tantric Buddhism, which were certainly an aspect assimilated by the Mongols (Heissig, 1980), have important elements in common with the antinomian dervish movements and associated figures such as Barak Baba. They included the deliberate flouting of convention as an aspect of religious asceticism, including the eating of forbidden foods, the use of drugs for transcendental purposes and dwelling in graveyards (Karamustafa, 1994).

\section{Timurid cultural eclecticism and Timur's own unorthodox religious beliefs}

According to Manz (1999), Timur's public religious affiliations were largely political. He cultivated powerful Sufi shayks who formed part of his inner circle and his primary allegiance was probably to the conservative Naqshbandi order. Timur's own religious practices were Islamic with an admixture of Turco-Mongolian shamanism (Manz, 1999, p. 17) and he "left an ambiguous record of flights of curiosity into the realms of unorthodox religious beliefs" (Etheredge, 2011, p. 112). The degree of cultural eclecticism in Timurid Herat may be judged by a court historian's description of the marriage festivities of Timur's son, quoted in Slobin (1976, p. 73).

Golden-tongued singers and sweet-sounding musicians played and sang to motives in Persian style, to Arab melodies according to Turkish practice and with Mongol voices, following Chinese laws of singing and Altai meters.

\section{CONCLUSIONS}

The most numerous accounts of the use of $A$. muscaria as an intoxicant are drawn from the indigenous peoples of Siberia. However, evidence for contemporary use has been recorded in Spain, Tibet, and Afghanistan. Its association with altered states of consciousness in European folklore (Fericgla, 2001) further suggests, together with linguistic evidence, that the use of $A$. muscaria as an inebriant was, and perhaps still is, much more widely diffused than is generally recognized. A. muscaria may have been an important inebriant before the availability of alcohol, which has displaced its use in recent history. As the product of such a cultural crossroads as 15 th century Herat, it no longer appears surprising that an image of a psychoactive mushroom should appear as the metaphorical means of ascent in a Timurid representation of the mi'raj, the ecstatic heavenly journey of the Prophet. Among the possible sources of this iconography are Pan-Eurasian shamanic practices shared in this case through Turkic contacts with Siberian peoples; the assimilation by Turkic peoples of the practices of Tantric Buddhism which evinces knowledge of A. muscaria; or local folk knowledge in Central Asia of the properties of Amanita as evidenced by the archaic practices of the Shutuli elders in the Hindu Kush.

Acknowledgements: The author would like to acknowledge the peer review process that considerably improved the paper and to thank Mike Crowley for drawing his attention to Seale's visual history of Burāq. He also reports no financial or other relationship relevant to the subject of this article.

Conflict of interest: The author declares no conflict of interest. 


\section{REFERENCES}

Balázs, J. (1996). The Hungarian Shaman's technique of trance induction. In V. Diószegi \& M. Hoppál (Eds.), Folk beliefs and shamanistic traditions in Siberia. Budapest, Hungary: Akadémiai Kiadó.

Barkalaja, A. (1997). On the sacrificial ritual of the Pim River Khanty in December 1995. In A. Leete (Ed.), Pro ethnologia 5: Arctic studies 1. Tartu, Estonia: Estonian National Museum.

Bourke, C. J. G. (1891). Scatalogic rites of all nations: A dissertation upon the employment of excrementitious remedial agents in religion, therapeutics, divination, witchcraft, love-philters, etc., in all parts of the globe/Based upon original notes and personal observation, and upon compilation from one thousand authorities. Washington, DC: W. H. Lowdermilk \& Co.

Cheremisin, D. V. (1997). The petroglyphs of the Left Bank of the Chuia (Gorny Altai). Journal of the Korean Ancient Historical Society, 10, 197-228. Retrieved from http://ambal. archaeology.nsc.ru/geni/Editions/Electronical/Bulletens/Herald/ Vol1/Default.htm

Crowley, M. (1996). When the Gods drank urine: A Tibetan myth may help solve the riddle of soma, sacred drug of ancient India. Fortean Studies, III, 176-188.

Culianu, I. (2001). Out of this world: Otherworldly Journeys from Gilgamesh to Albert Einstein. Boston, MA: Shambhala.

Dankoff, R. (1971). Baraq and Burāq. Central Asiatic Journal, 15.2, 102-117. Retrieved from https://www.jstor.org/stable/ 41926898

de Hartog, L. (2004). Genghis Khan: Conqueror of the world. New York, NY: Tauris Parke.

Devlet, E. (2008). Rock art studies in the far East and Russia, 2002-2004. In P. Bahn, N. Franklin, \& M. Strecker (Eds.), Rock art studies: News of the world (Vol. 3). Oxford, UK: Oxbow Books.

Eliade, M. (2004). Shamanism: Archaic techniques of Ecstasy. Princeton, NJ: Princeton University Press.

Etheredge, L. (Ed.). (2011). Iran (Middle East: Region in transition) (p. 112). New York, NY: Rosen Publishing.

Fericgla, J. M. (1992). A. muscaria usage in Catalunya. In H. de Vries (Ed.), Integration: Journal for mind-moving plants and culture (Number 2 and 3, Special Mushroom Issue). Eschenau, Austria: Bilwis-Verlag.

Fericgla, J. M. (2001). El Hongo y la Genesis De Las Culturas: Duendes y Gnomos Ambitos Culturales Forjados por el Consumo de la Seta Enteogena A. muscaria [Fungi and the genesis of cultures. Goblins and gnomes: Cultural fields forged by the consumption of the entheogenic mushroom $A$. muscaria]. Barcelona, Spain: La Liebre de Marzo.

Flattery, D. S., \& Schwartz, M. (1992). Haoma and harmaline: The botanical identity of the Indo-Iranian sacred Hallucinogen "Soma" and its legacy in religion, language, and MiddleEastern Folklore. Berkley, CA: University of California Press.

Furst, P. (1986). Mushrooms: Psychedelic fungi (Encyclopedia of psychoactive drugs series). New York, NY: Chelsea House Publishers.

Golovnev, A. (Director). (2001). Pegtymel [DVD]. Hanover, NH: Institute of Arctic Studies.

Gosso, F., \& Webster, P. (2014). The dream on the rock: Visions of prehistory. New York, NY: State University of New York Press.
Graves, C. (1994). Proto-religions in Central Asia. Bochum publications in evolutionary cultural semiotics (Vol. 34). Bochum, Germany: Brockmeyer.

Gruber, C., \& Colby, F. (Eds.). (2010). The Prophet's ascension: Cross-cultural encounters with the Islamic Mi'raj Tales. Bloomington, IN: Indiana University Press.

Hajicek-Dobberstein, S. (1995). Soma siddhas and alchemical enlightenment: Psychedelic mushrooms in Buddhist tradition. Journal of Ethnopharmacology, 48(2), 99-118. doi:10.1016/ 0378-8741(95)01292-L

Hajjāj, A.-A. (1989). The Isrā and Mi'rā. The prophet's night journey and ascent into heaven. London, UK: Dar Al-Taqwa.

Haug, M., \& West, E. (Trans.). (1971). The book of Arda Viraf. Amsterdam, Netherlands: Oriental Press.

Heissig, W. (1980). The religions of Mongolia. London, UK: Routledge and Kegan Paul.

Karamustafa, A. T. (1994). God's unruly friends: Dervish groups in the Islamic middle period 1200-1550. Salt Lake City, UT: University of Utah Press.

Keightley, T. (2000). The world guide to gnomes, fairies, elves \& other little people. New York, NY: Gramercy Books.

Kiriak, M. (2007). Early art of the northern Far East: The Stone Age. Anchorage, Alaska: U.S. Department of the Interior, National Park Service, Shared Beringian Heritage program.

Lincoff, G. (2005, October). Is the fly-agaric (Amanita muscaria) an effective medicinal mushroom? Paper presented at The Third International Medicinal Mushroom Conference, Port Townsend, Washington. Retrieved from www.nemf.org/files/ various/muscaria/fly_agaric_text.html

Manz, B. F. (1999). The rise and rule of Tamerlane. Cambridge, UK: Cambridge University Press.

Melville, G. W. (1885). In the Lena Delta. Boston, MA: Houghton Mifflin.

Michelot, D., \& Melendez-Howell, L. (2003). A. muscaria: Chemistry, biology, toxicology, and ethnomycology. Mycological Research, 107(2), 131-146. doi:10.1017/S0953756203 007305

Miller, H. (2001). The mystery of Zulu Dawn. More secrets of the dead. London, UK: Channel 4 Books.

Mochtar, S., \& Geerken, H. (1979). Die Halluzinogene Muscarin und Ibotensäure im Mittleren Hindukusch: Ein Beitrag zur volkheilpraktischen Mykologie [The hallucinogens muscarine and ibotenic acid in the Middle Hindu Kush: A contribution on traditional medicinal mycology] (Peter G. Werner, Trans.]. Afghanistan Journal, 6, 62-65. Retrieved from www.erowid.org/plants/amanitas/references/journal/1979_ mochtar_afghanistan 1. shtml

Morgenstierne, G. (1957). 'Mushroom' and 'toadstool' in Indo-Iranian. Bulletin of the School of Oriental and African Studies, 20(1), 451-457. doi:10.1017/S0041977X0006198X

Müller-Ebeling, C., Ratsch, C., \& Shahi, S. B. (2000). Shamanism and Tantra in the Himalayas. London, UK: Thames and Hudson.

Munn, H. (1973). The mushrooms of language. In M. Harner (Ed.), Hallucinogens and shamanism (pp. 86-122). New York, NY: Oxford University Press.

Nicolle, D. (1998). The Mongol Warlords. London, UK: Brockhampton Press.

Országh, L. (1987). Magyar-Angol Kézistótár (11th ed.). Budapest, Hungary: Akadémia Kiadó. 
Peschel, K. (1998). Puhpohwee for the people, an account of fungi uses among the Ahnishinaabeg. DeKalb, IL: LEPS Press.

Saar, M. (1991). Fungi in Khanty folk medicine. Journal of Ethnopharmacology, 31(2), 175-179. doi:10.1016/0378-8741 (91)90003-V

Salzman, E., Salzman, J., Salzman, J., \& Lincoff, G. (1996). In search of Mukhomor, the mushroom of immortality. Shaman's Drum, 4, 36-47. Retrieved from http://bigmedia.org/aboutjason-salzman/19929-2/

Schurr, Th. G. (1995). Aboriginal Siberian use of Amanita muscaria in shamanistic practices: Neuropharmacological effects of fungal alkaloids Ingested during trance induction, and cultural patterning of visionary experience. Curare. Zeitschrft für Ethnomedizin, 18(1), 31-65. Retrieved from http://52.33.200.251/bibliography/default/resource/15573

Seale, Y. (2016). Out of their love they made it: A visual history of Buraq. Public Domain Review. Retrieved from https:// publicdomainreview.org/2016/09/21/out-of-their-love-theymade-it-a-visual-history-of-buraq/

Seeger, R., \& Stijve, T. (1978). Occurrence of toxic Amanita species, in Amanita toxins and poisoning. In H. Faulstich, T. Wieland, \& B. Kommerell (Eds.), Amanita toxins and poisoning. Baden-Baden, Germany: Verlag Gerhard Witzrock.

Séguy, M.-R. (1977). The miraculous journey of Mahomet. Mirâj Nâmeh. Introduction and commentaries by Marie-Rose Séguy. London, UK: The Scholar Press.
Slobin, M. (1976). Music in the culture of Northern Afghanistan (p. 73). Tucson, Ariz: University of Arizona Press.

Stimson, T. (Director and Producer). (1999). Song of Mukhomor [DVD]. Denver, CO: Privately produced.

Stone, A. (1992). Flying to the cloud: Soma and the Axis Mundi. Mercian Mysteries, No. 13.

Stone, A. (2003). Explore shamanism. Loughborough, UK: Heart of Albion Press.

Vuckovic, B. (2005). Heavenly journeys, earthly concerns: The legacy of the Mi'raj in the formation of Islam. New York, NY: Routledge and Kegan Paul.

Waldemar, J. (Auth.), Kasten E., \& Dürr M. (Eds.). (2016). The Koryak, Verlag der Kulturstiftung Sibirien. Norderstedt, Germany: SEC Publications.

Wasson, R. G. (1972). Soma: Divine mushroom of immortality. San Diego, CA: Harcourt Brace Jonavich.

West, E. (Trans.). (1987). Denkard. In Sacred books of the East (Vol. 5). Oxford, UK: Oxford University Press.

White, D. G. (2003). Kiss of the Yogini. Tantric sex in its South Asian Contexts. Chicago, IL: University of Chicago Press.

Zarcone, T., \& Hobart, A. (Eds.). (2016). Shamanism and Islam. London, UK: I.B. Tauris.

Zsigmond, G. (2003). The Amanitaceae in Hungarian folk tradition. In P.-F. Ferenc \& G. Zsigmond (Eds.), Moeszia. Erdélyi Gombász (Vol. 1, pp. 55-68). Sf. Gheorghe, Romania: Periodical of the Kálmán LÁSZLÓ Mycological Society. 